\title{
THE ROLE OF P.N.F. TECHNIQUES IN THE RECOVERY OF THE PARALYSIS OF EXTERNAL POPLITEAL SCIATIC NERVE
}

\author{
Ochiană Gabriela ${ }^{1 *}$ \\ Ochiană Nicolae ${ }^{2}$ \\ Ochiană Mircea-Alex ${ }^{3}$ \\ 1,2,3University "Vasile Alecsandri", Mărășești 157, Bacau, 600115, Romania
}

Keywords: motor deficit, mobility, nerve, lower limb, recovery, facilitation.

\begin{abstract}
The recovery of the motor deficit caused by neurapraxia is indispensably linked to the removal of the compression on the nerve and to a recovery strategy based on the facilitation of a motor response. The study was carried out on a 32-year-old patient with comminuted fracture of the lower third of the left femur, for which she had a surgical intervention, the fracture being stabilized using a metal plate and screws. The programme was made up of: stimulating massage, facilitation techniques in an open kinetic chain, then in a closed kinetic chain using the gym ball, the medicinal ball and the cane, exercises for the re-education of sensitivity, exercises using different objects, exercises using the wall ladder, pedalling on the ergonomic bike, etc. The results achieved confirm the hypothesis formulated in the beginning; thus, the recovery of the sensory-motor deficit was achieved in 3 months, compared to the 6-9-month period normally estimated, thus halving the recovery period.
\end{abstract}

\section{Introduction}

Traumatic paralyses of the leg can affect both the common trunk of the sciatic nerve and the two terminal branches: more frequently the external popliteal sciatic nerve, as well as the internal popliteal nerve. The severity and the prognosis depend on the type of nerve injury (neurapraxia, axonotmesis, neurotmesis) (Sbenghe, 1981, p. 403). The causes of paralyses can be: fractures, luxations, concussions, external compression due to a plaster cast, tractions for treating fractures, etc. External popliteal sciatic nerve damage can be achieved all along the pathway of the nerve, but it occurs more frequently in the popliteal area and at the end of the peroneal nerve, and it can be compressed with a simple circular cast. Paralysis of the main trunk of the external popliteal sciatic nerve (the superficial peroneal nerve and the anterior tibial nerve) causes the inability of performing dorsal flexion, eversion and extension of the toes, the

*E-mail: gabi_ochiana@yahoo.com; 
foot is in varus-equin position and the walking pattern is stepped (with a limp). The recovery time necessary is of 15.5 months in case of full damage and 9.5 months in incomplete damage (Sbenghe, 1981).

Neuromuscular facilitation is a treatment concept that uses various and repetitive stimuli (under $10 \mathrm{msec}$.) which lead to the recruitment and the activation of supplementary motor units, thus triggering a motor response on the level of the functionally inactive muscles, paretic or palsied muscles (Adler, Beckers \& Buck, 2003, pp.1-170; Ochiană, Ochiană \& Pintilie, 2010). The ability of applying these techniques, selecting the most efficient ones and the communication with the patient are essential in order to achieve an efficient motor response from the palsied muscles, as well as to increase the muscular strength force afterwards (Ochiană, 2013). The recovery of palsied muscles based on the use of facilitation techniques may shorten the recovery time and restore the correct and balanced walking much faster (Bly \& Whiteside, 1997).

\section{Material and methods}

Our hypothesis was that: if, during the functional recovery programme, we use neuromuscular facilitation techniques such as: repeated contractions (RC), active relaxation-opposition movement (AROM), fortification sequencing (FS), slow reversal (SR), slow reversal with opposition (SRO), alternating isometrics (AIs) and rhythmic stabilisation (RS) according to the motor response, we will achieve a more accelerated recovery of the motor control and we will shorten the recovery period.

The study was carried out on a 32-year-old patient with comminuted fracture of the lower third of the left femur, for which she had a surgical intervention, the fracture being stabilized using a metal plate and screws. After a six-week plaster cast immobilization, a total motor deficit for the dorsiflexion and eversion (F0) could be noticed. The electromyogram confirms the absence of sensory-motor control on the pathway of the external popliteal sciatic nerve, and that is why a neurolysis of the external popliteal and posterior tibial sciatic nerve was carried out at Sf. Spiridon Hospital in Iasi.

For the assessment we used: the visual examination and palpation, measuring the thigh and shank circumference, assessing the pain during the palpation of post-operative scars and joint mobilisation, testing the sensitivity (0-2 scale), the muscular strength (0-5 scale), the active joint mobility, the walk and the x-ray. The functional diagnosis after the assessment was: pain during the palpation of post-operative scars and during the flexion of the shank on the thigh, muscle atrophy in the left shank and thigh, paresthesia on the anterolateral side of the shank, motor deficit on the dorsal flexors and eversors of the ankle and 1-2 toe extensors (F0), decreased active joint mobility during the flexion of the shank on the thigh, dorsal flexion and eversion and 1-2 toe extension, pelvis sinking to the right, walking with crutches, without putting any weight on the left lower limb. 
The recovery programme included: stimulating massage on the palsied shank muscles, stimulating massage of the thigh and smoothing massage on the post-operative scars, stretch-reflex, repeated contractions, active relaxationopposition movements for the peroneus muscles, tibialis anterior muscle and toe extensor muscles, fortification sequencing with opposition on the iliopsoas and quadriceps in order to facilitate dorsal flexion, myotensive technique for the quadriceps and ischia-shink area, slow reversal, slow reversal with opposition and isometric contractions in the shortened area on the shank, knee and hip muscles, alternating isometrics and rhythmic stabilisation for the same groups of muscles, as well as the use of these techniques on the Kabat diagonals for flexion and extension, in order to train the muscle chains of the lower limb.

In order to improve joint mobility on the level of the knee for the flexion, we used cryotherapy by applying a bag of cold gel for 3-5 minutes (decreasing the pain), then we used the myotensive technique for the quadriceps and isometric stretching, alternating isometrics and rhythmic stabilisations to the maximum flexion.

In order to improve proprioception, stability and balance, we used the gym ball, the wobble balance board, exercises using the wall ladder, and in order to re-educate the normal walk we used the normal sequencing, progression with resistance, walking over obstacles, etc.

\section{Results and discussions}

After applying the recovery programme presented above, with sessions lasting for 60-80 minutes and a frequency of 5 sessions per week during the first month, 3 sessions a week during the next 2 months and 2 sessions a week for the last 3 months, there was visible improvement in trophicity, as it follows from the diagram no.1.

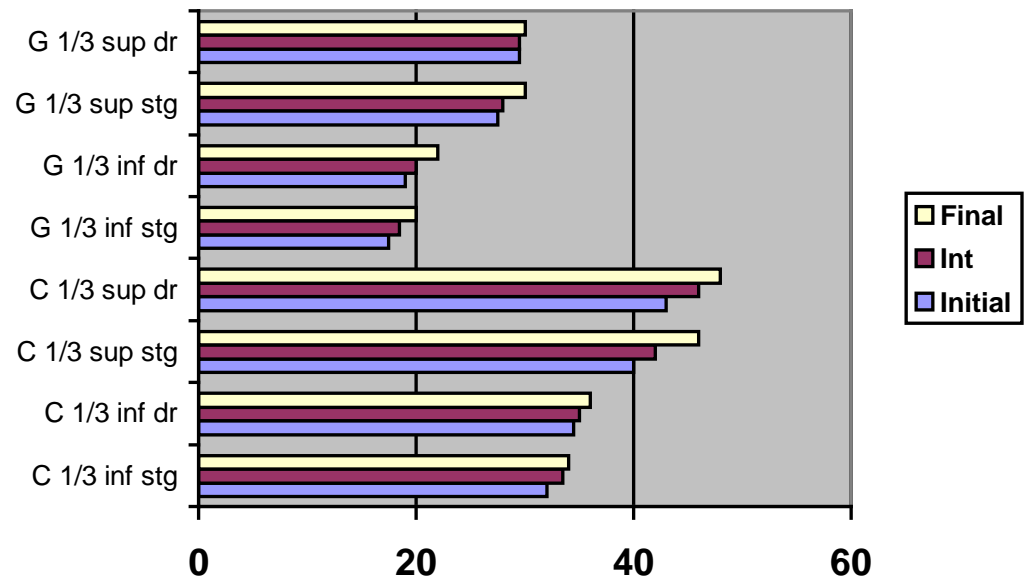

Figure 1. Comparative values of the thigh and shank circumference for the right and left lower limb 
After the physical therapy intervention, the left shank and thigh circumference increased visibly, by $2 \mathrm{~cm}$ on the level of the lower third of the left thigh and by $6 \mathrm{~cm}$ on the upper third, with a final difference of $2 \mathrm{~cm}$ between the circumferences of the right and left thigh, compared to the initial testing when the difference was of $3 \mathrm{~cm}$. As it follows from diagram 1, the diameter of both left and right thighs increased due to the physical therapy intervention applied on both lower limbs.

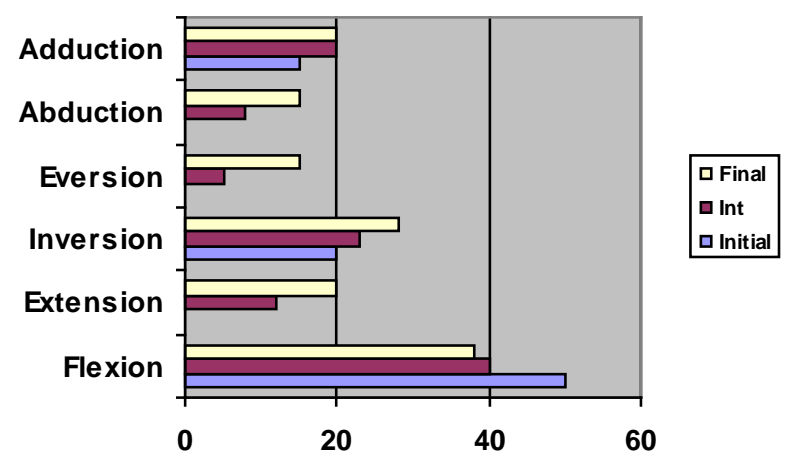

Figure 2. Values of joint mobility on the level of ankle

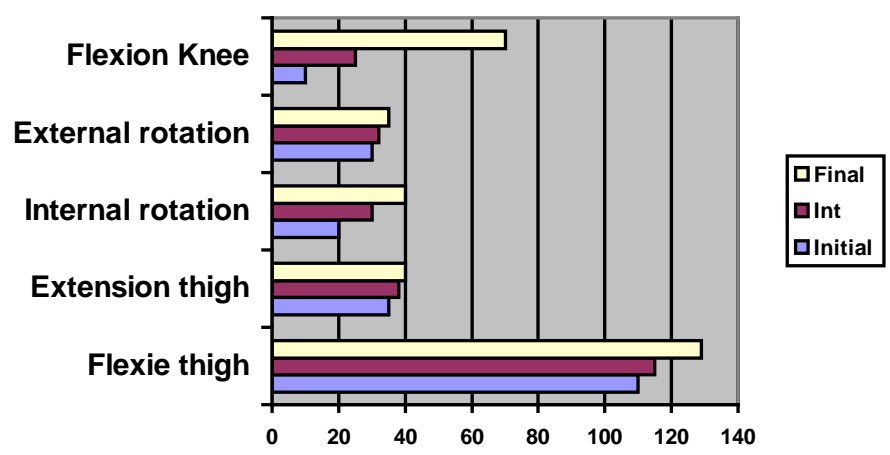

Figure 3. Values of joint mobility on the level of thigh and knee

As we can see in diagram no.2, the active joint mobility increased visibly, especially during the extension movement (dorsal flexion), eversion and adduction of the ankle, from values of 0 degrees to 20 degrees for dorsal flexion and 15 degrees for eversion and abduction, which means a difference of 15-20 degrees in the active mobility compared to the 0 degrees recorded initially.

Moreover, if during the initial testing the plantar flexion had values of 50 degrees, in the end it dropped to 38 degrees due to the recovery of the muscle balance between agonist and antagonist muscles (flexors and extensors). In diagram no.3 we can see the thigh mobility which improved, as well as the knee mobility which registered high values in the end, from 10 degrees to 70 degrees, with a significant difference of 60 degrees. 


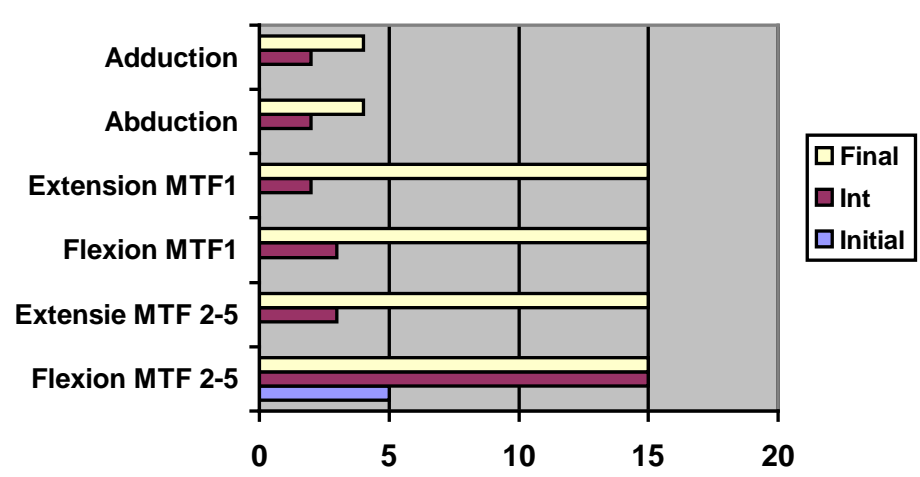

Figure 4. Values of joint mobility on the level of the toes

Visible progress was achieved for the toe extension, flexion and abduction movement, reaching values of 15 degrees in the end, compared to 0 degrees registered initially (toe extension and hallux flexion and extension), diagram no. 4.

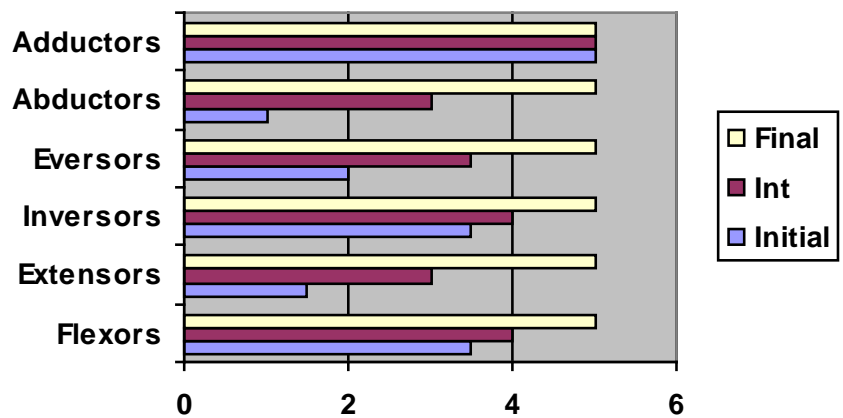

Figure 5. Values of the muscular strength on the level of the ankle

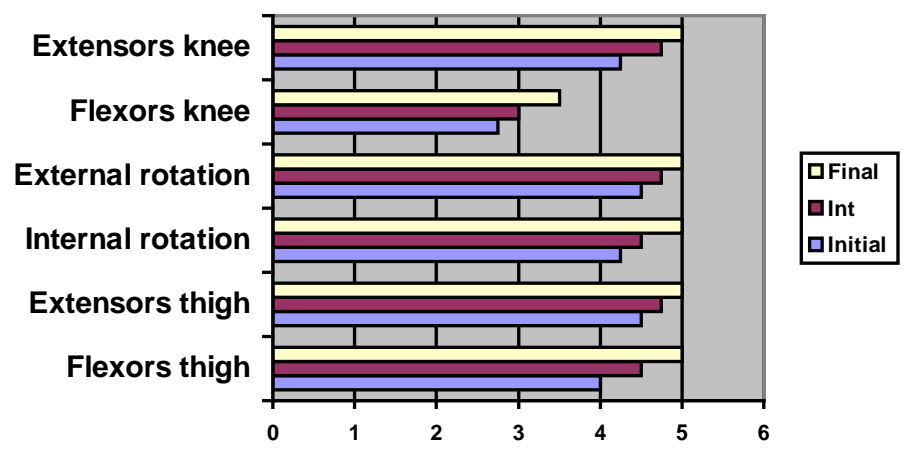

Figure 6. Values of the muscular strength on the level of the thigh and knee

The muscular strength on the level of the more affected ankle increased, reaching in the end values of 5 for the dorsal flexion and eversion movement, compared to values of 1.5 and 2 recorded initially, thus re-establishing balance between flexors and extensors, invertors and eversors, balance necessary for a 
stable and well-balanced walk, diagram no.5. The muscular strength also increased on the level of the knee, both for flexors (from 2.75 to 3.5) and for extensors (from 4.4 to 5), diagram no.6.

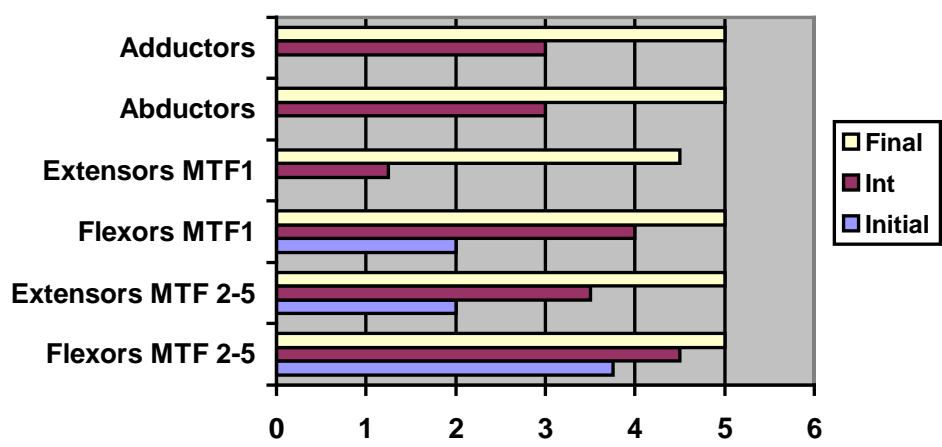

Figure 7. Values of the muscular strength on the level of the toes

Good results were also achieved in muscular strength (diagram no.7) on the level of the toes. Thus, for the flexors of the toes 2-5 the muscular strength increased to 5, from the initial value of 3.5, while for the hallux the strength increased from 2 to 5 . In the case of the hallux extensors (F0 initially), the muscular strength increased to 5 and in the case of the extensors of the toes 2-5 the strength increased from 2 to 5 ; the toe abductors had in the end a strength of 5 , compared to 0 registered initially. The increase in muscular strength means in fact the recovery of the nerve pathway and a normal innervation of the muscles affected.

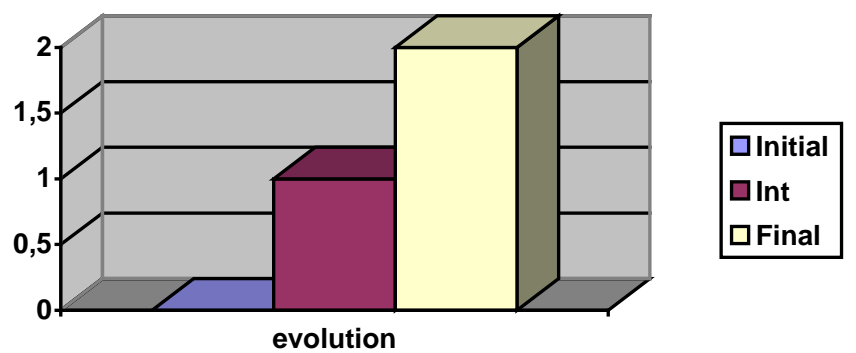

Figure 8. Evolution of the cutaneous sensitivity

As it follows from diagram no. 8 and from table no.4, the sensitivity came back to normal values (2) from hypoesthesia (0) on the level of the anteroexternal side of the shank and the foot.

The recovery of the paralysis of external popliteal sciatic nerve through post-operative neurapraxia after removing the nerve compression has various duration, between 6 and 9 months, and it supposes a specific strategy based on the use of the normally innervated muscles in order to influence the palsied 
muscles, phenomenon known in the literature as facilitation. The duration of the recovery depends on: the early start of the recovery, the patient's motivation, le specialist's qualification level in using the proper techniques, procedures and methods specific to the different stages of the treatment.

\section{Conclusions}

In this study concerning the role of the facilitation techniques in the recovery of the paralysis of external popliteal sciatic nerve through postoperative neurapraxia, the hypothesis which was our starting point was confirmed. Consequently, certain conclusions can be drawn as follows:

- The use of stretch-reflex, repeated contractions, active movements of relaxation-opposition on the palsied muscles and of the fortification sequencing for the normal muscles (in order to influence the affected muscles) during the muscle hypotonia period (F0-1) accelerates the motor response;

- Applying the slow reversion and slow reversion with opposition (F 2-4) is efficient in regaining balance between agonists and antagonists, by adapting the resistance opposing to the momentum of the muscle;

- The alternating isometrics and the rhythmic stabilisation increase the muscular strength and the joint stability by contracting simultaneously the agonists, antagonists, synergists and fixators;

- Selecting the most efficient facilitation techniques, according to the strength of the muscle, is essential in order to accelerate the motor response.

Finally, the role of the facilitation techniques in the functional recovery of the nerve is indisputable, an essential part being their selection according to: the type of nerve damage, the muscle strength, the practical ability and the patienttherapist communication; all these culminate in halving the recovering time compared to the use of the classical recovery methods.

\section{References}

1. ADLER, S., BECKERS, D., BUCK, M. (2003). PNF in practice. Second, revised edition, Berlin, Heidelberg: Springer, 1-170, Germany;

2. BLY, L., WHITESIDE, A. (1997). Facilitation Techniques Based on NDT Principles, San Antonio, Tex: Therapy Skill Builders, SUA;

3. OCHIANĂ, G. (2013). Kinetoterapia în afecțiuni neurologice: curs pentru studenţii programului de studii de licenţă Kinetoterapie şi motricitate specială, Bacău: Alma Mater, Romania;

4. OCHIANĂ, G., OCHIANĂ, N., PINTILIE, M. (2010). The role of electrotherapy and physiotherapy in treating the external popliteal nerve paresis, Gymnasium 1 (XI), 93-99, Bacău, Romania;

5. SBENGHE, T. (1981). Recuperarea medicală a sechelelor posttraumatice ale membrelor, Bucureşti: Medicală, 403, Romania;

6. SBENGHE, T. (1987). Kinetologie profilactică, terapeutică şi de recuperare, Bucureşti: Medicală, Romania. 


\title{
ROLUL TEHNICILOR F.N.P. ÎN RECUPERAREA PARALIZIEI DE SCIATIC POPLITEU EXTERN
}

\author{
Ochiană Gabriela 1 \\ Ochiană Mircea-Alex ${ }^{2}$ \\ Ochiană Nicolae ${ }^{3}$ \\ 1,2,3Universitatea “Vasile Alecsandri”, Mărășești 157, Bacău, 600115, Romania
}

Cuvinte cheie: deficit motor, mobilitate, nerv, membrul inferior, recuperare, facilitare.

\section{Rezumat}

Recuperarea deficitului motor determinat de neurapraxie, este legată indispensabil de îndepărtarea compresiunii nervului şi de abordarea unei strategii de recuperare axată pe facilitarea reapariţiei răspunsului motor. Studiul s-a realizat pe o pacientă de 32 de ani cu fractură cominutivă 1/3 inferioară femur stâng pentru care s-a intervenit chirurgical, fractura fiind stabilizată cu placuta de metal şi şuruburi. Programul a fost alcătuit din: masaj stimulativ, tehnici de facilitare în lanţ cinetic deschis, apoi închis prin folosirea gymball-ului, a mingii nedicinale şi bastonului, exerciţii pentru reeducarea sensibilităţii, exerciţii cu obiecte, la spalier, pedalare la bicicleta ergometrică, etc. Rezultatele obţinute confirmă ipoteza formulată, astfel, refacerea deficitului motor şi a sensibilităţii s-a realizat în 3 luni de zile, comparativ cu o durată de 6-9 luni în mod normal, scurtând în acest fel la jumătate durata de recuperare.

\section{Introducere}

Paraliziile traumatice ale piciorului pot interesa atât trunchiul comun al nervului sciatic, cât şi cele două ramuri terminale: sciaticul popliteu extern, mai frecvent, şi sciaticul popliteu intern; iar gravitatea şi prognosticul depinde de tipul de afectare a nervului (neuropraxia, axonotmesis, neurotmesis) (Sbenghe 1981, p.403). Cauzele paraliziilor pot fi: fracturi, luxaţii, contuzii, compresiune externă prin aparat gipsat, tracţiuni pentru redresarea fracturii, etc. Lezarea nervului sciatic popliteu extern, se poate realiza pe tot traiectul, dar cel mai frecvent în zona poplitee şi la capul peroneului unde este localizat superficial, şi poate fi comprimat cu un simplu gips circular. Paralizia trunchiului comun al sciaticului popliteu extern (nervul peronier superficial şi tibial anterior) determină imposibilitatea de a efectua flexia dorsală, eversia şi extensia degetelor, piciorul este în poziţie de varus-equin, iar mersul se realizează stepat. Timpul necesar recuperării este de 15,5 luni în leziunile complete şi 9,5 luni în cele incomplete (Sbenghe, 1981).

Faciliarea neuro-musculară, este un concept de tratament care foloseşte stimuli de natură variată şi repetitivă (sub 10 msec.) care să determine recrutarea şi activarea de unităţi motorii suplimentare, determinând apariţia unui răspuns motor la nivelul muşchilor inactivi funcţional, paretici sau paralizaţi (Adler, 
Beckers \& Buck, 2003, p. 1-170; Ochiană G., Ochiană N. \& Pintilie, 2010). Abilitatea de aplicare practică a acestor tehnici, selectarea celor mai eficiente şi modalitatea de comunicare cu pacientul sunt esenţiale pentru obţinerea unui răspuns motor eficient din partea muşchilor paralizaţi, dar şi pentru creşterea ulterioară a forţei musculare (Ochiană, 2013). Recuperarea muşchilor paralizaţi axată pe folosirea tehnicilor de facilitare poate determina scurtarea timpului şi reluarea mai rapidă a mersului corect şi echilibrat (Bly \& Whiteside, 1997).

\section{Material şi metode}

Ipoteza de la care am plecat, a fost: dacă în programul de recuperare funcţională, voi folosi tehnici de facilitare neuro-musculară cum sunt: contracţiile repetate (CR), mişcarea activă de relaxare opunere (MARO), secvenţialitatea pentru întărire (Ŝ̂), inversarea lentă (IL), inversarea lentă cu opunere (ILO), izometria alternantă (IzA) şi stabilizarea ritmică (SR) în funcţie de apariţia răspunsului motor, voi obţine o refacere mai rapidă a controlului motor şi scurtarea timpului de recuperare.

Studiul s-a realizat pe o pacientă de 32 de ani cu fractură cominutivă $1 / 3$ inferioară femur stâng pentru care s-a intervenit chirurgical la Spitalul Judeţean Bacău, fractura fiind stabilizată cu plăcuţă de metal şi şuruburi. După imobilizarea în aparat gipsat 6 saptămâni, după îndepărtarea acestuia, s-a constatat un deficit motor total pentru mişcarea de flexie dorsală şi eversie (F0) şi tulburări de sensibilitate pe partea antero-posterioară a gambei. Electromiograma confirmă absenţa controlului motor şi senzitiv pe traiectul nervului sciatic popliteu extern, motiv pentru care s-a realizat neuroliza nervului sciatic popliteu extern şi tibial posterior la spitalul Sf. Spiridon din Iaşi.

Pentru evaluare, am folosit: examenul vizual şi palpatoriu, măsurarea circumferinţei coapsei şi gambei, evaluarea durerii la palparea cicatricilor operatorii şi mobilizare articulară, testarea sensibilităţii (scala 0-2), a forţei musculare (scala 0-5), a mobilităţii articulare active, mersul precum şi radiografia.

Diagnosticul funcţional în urma evaluării, a fost: durere prezentă la palparea cicatricii operatorii şi la flexia gambei pe coapsă, atrofie musculară la nivelul ganbei şi coapsei stângi, parestezii pe partea antero-externă a gambei, deficit motor pe flexorii dorsali si eversori ai gleznei şi extensori deget 1-2 (F0), scăderea mobilitatii articulare active pe mişcarea de flexie a gambei pe coapsă, flexie dorsala si eversie si extensie deget 1-2, bazinul înclinat oblic-stânga sus, mersul se realizeaza cu cârje fără sprijin pe membrul inferior stâng.

Programul de recuperare a cuprins: masaj stimulator pe musculatura paralizată de la nivelul gambei, stimulativ la nivelul coapsei şi asuplizant la nivelul cicatricilor operatorii, strech-reflex, contracţii repetate, mişcarea activă de relaxare opunere pentru peronieri, tibial anterior şi extensori degete, secvenţialitatea pentru întărire cu aplicarea reistenţei pe psoas iliac şi cvadriceps pentru facilitarea flexiei dorsale, miotensive pentru cvadriceps şi ischiogambieri, inversare lentă, inversare lentă cu opunere şi contracţia izometrică în zona 
scurtată pe musculatura gleznei, genunchiului şi a şoldului, izometria alternantă şi stabilizarea ritmică pentru aceleaşi grupe musculare, precum şi folosirea acestor tehnici pe diagonalele Kabat de flexie şi extensie, pentru antrenarea lanţurilor musculare a membrului inferior.

Pentru creşterea mobilităţii articulare la nivelul genunchiului pe mişcarea de flexie, am folosit crioterapia prin aplicarea unei pungi cu gel rece timp de 3-5 minute (scăderea durerii), apoi am folosit miotensive pentru cvadriceps şi stretchingul izometric, izometria alternantă şi stabiliarea ritmică la limita de flexie posibilă.

Pentru refacerea propriocepţiei, a stabilităţii şi echilibrului am folosit gymball-ul, planşeta de echilibru, exerciţiile la spalier, iar pentru refacerea unei scheme normale de mers, am utilizat secvenţialitatea normală, progresia cu rezistenţă mersul cu peste obstacole etc.

\section{Rezultate și discuţii}

În urma aplicării programului de recuperare prezentat mai sus cu o durată de 60-80 minute şi o frcvenţă de 5 şedinţe pe săptămână în prima lună, apoi 3 pe săptmână în următoarele 2 luni şi 2 pe săptîmână în ultimele 3 luni, troficitatea s-a îmbunătăţit vizibil, aşa cum reiese din graficul nr.1.

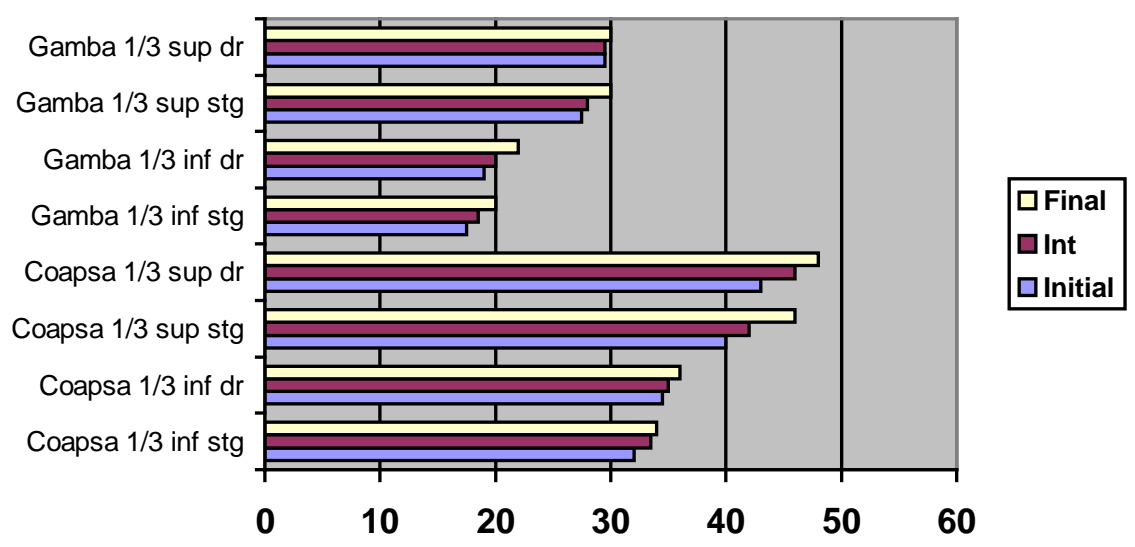

Figura 1. Valorile circumferinţei gambei şi coapsei comparativ membrul inferior drept şi stâng

În urma aplicării intervenţiei kinetoterapeutice, circumferinţa gambei şi coapsei stângi a crescut vizibil, respectiv cu $2 \mathrm{~cm}$ la nivelul $1 / 3$ inferioare a coapsei stângi şi cu $6 \mathrm{~cm}$ la nivelul 1/3 superioare, fiind o diferenţă finală de 2 $\mathrm{cm}$ între circumferinţa coapsei stângi şi drepte, comparativ cu testarea iniţială, când diferenţa era de $3 \mathrm{~cm}$.

Aşa cum reiese din graficul nr. 1, a crescut diametrul atât a coapsei stângi cât şi a celei drepte ca urmare a intervenţiei kinetoterapeutice aplicatî pe ambele membre inferioare. 
Aşa cum se observă din graficul nr. 2, mobilitatea articulară activă a crescut vizibil, în special pentru mişcarea de extensie (flexie dorsală), eversie şi abducţie a gleznei, de la valori de 0 grade la 20 grade pentru flexie dorsală, 15 grade pentru eversie şi abducţie, ceea ce reprezintă o diferenţă de 15-20 de grade mobilitate activă comparativ cu 0 grade iniţial.

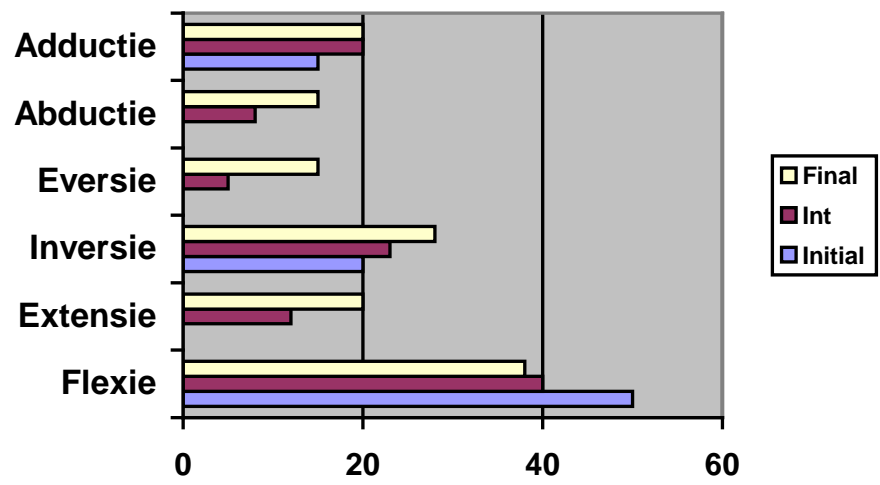

Figura 2. Valorile mobilităţii articulare la nivelul gleznei

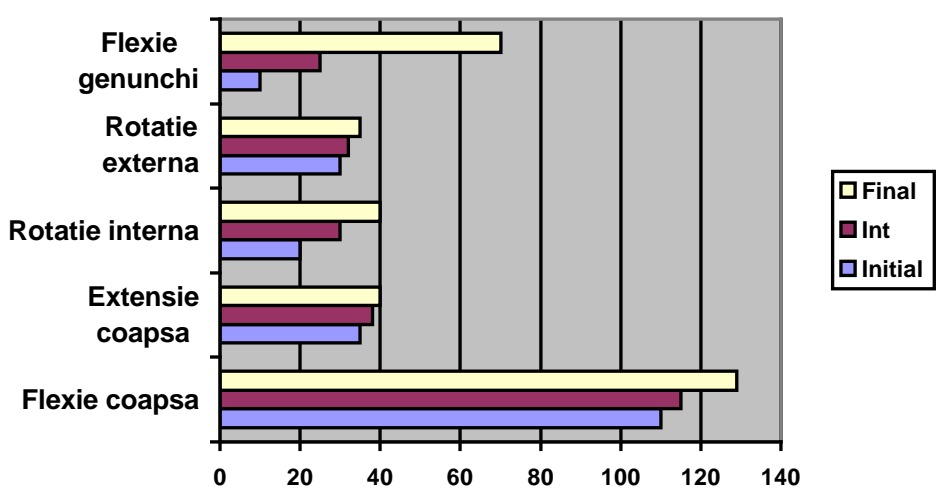

Figura 3. Valorile mobilităţii articulare la nivelul coapsei şi genunchiului

De asemenea, dacă la evaluarea iniţială flexia plantară avea valori de 50 grade, la final a scăzut la 38 grade, datorită restabilirii echilibrului muscular dintre agonişti şi antagonişti (flexori şi extensori).

În graficul nr. 3 este redată mobilitatea coapsei, care s-a îmbunătăţit, precum şi a genunchiului care a înregistrat valori mari la final, de la 10 grade la 70 grade, fiind o diferenţă semnificativă de 60 de grade. 


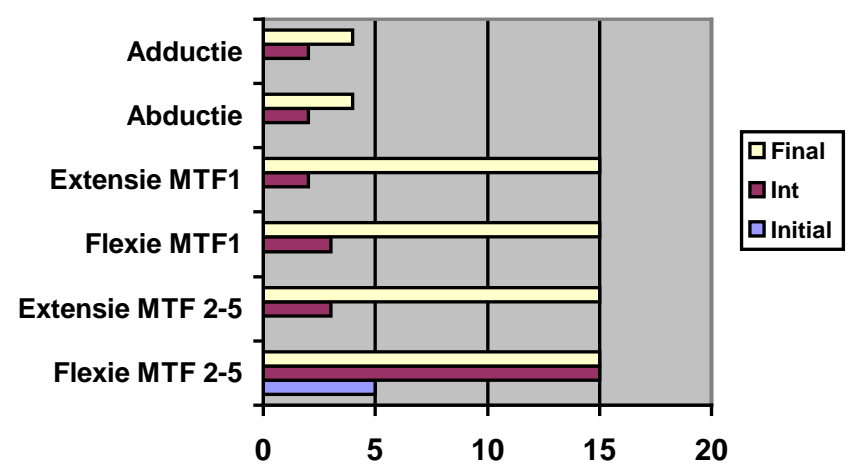

Figura 4. Valorile mobilităţii articulare la nivelul degetelor

Progrese vizibile s-au obţinut pe mişcarea de extensie, flexie şi abducţie a degetelor, ajungându-se la valori de 15 grade la final, comparativ cu 0 grade iniţial (extensia degetelor şi flexia şi extensia halucelui), graficul nr. 4.

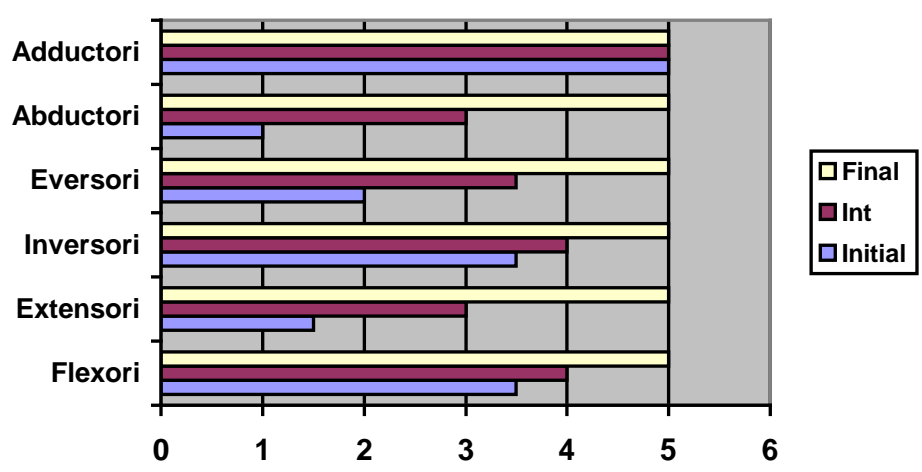

Figura 5. Valorile forţei musculare la nivelul gleznei

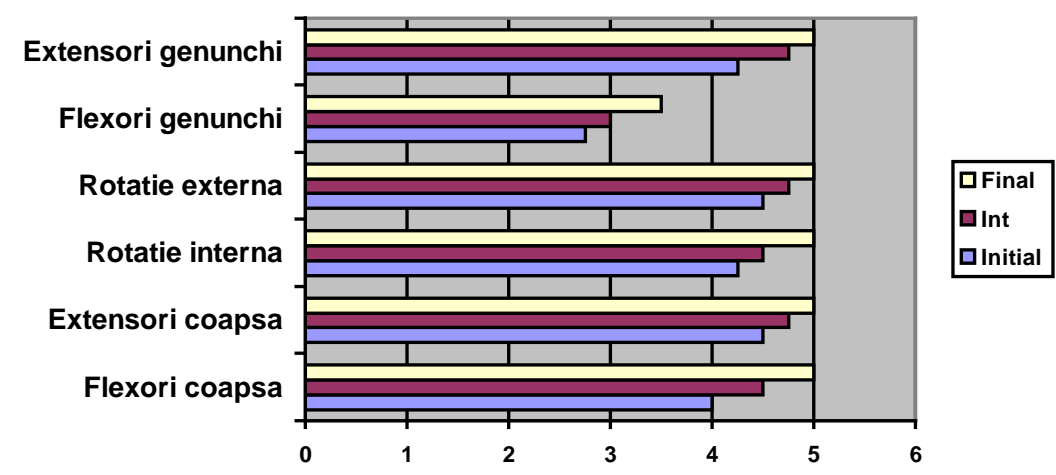

Figura 6. Valorile forţei musculare la nivelul coapsei şi genunchiului 
Forţa musculară de la nivelul gleznei care a fost cea mai afectată, a crescut, ajungând la final la valori de 5 pentru mişcarea de flexie doesală şi eversie, de la valori de 1,5 şi 2, restabilindu-se în acest fel echilibrul dintre flexori-extensori, inversori-eversori necesar în realizarea unui mers stabil şi echilibrat, graficul nr. 5. De asemenea, a crescut şi forţa musculară la nivelul genunchiului, atât pentru flexori de la 2,75 la 3,5, cât şi pentru extensori, de la 4,4 la 5.

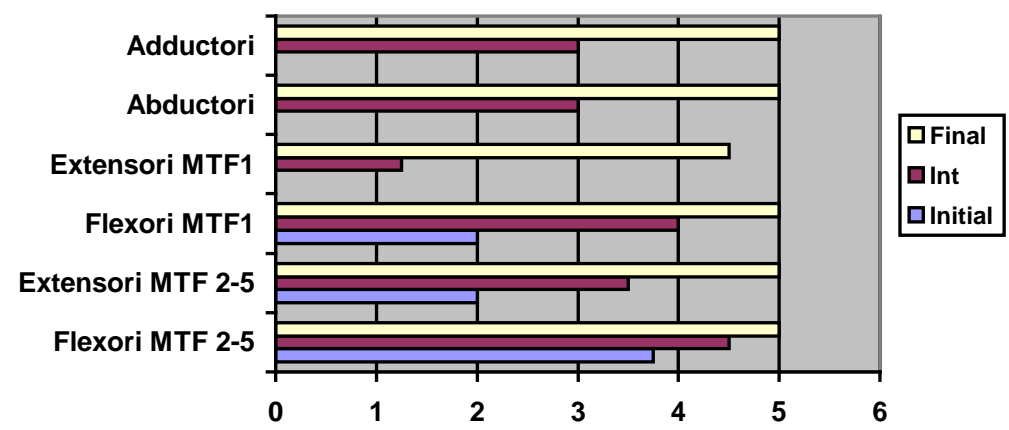

Figura 7. Valorile forţei musculare la nivelul degetelor

Rezultate bune s-au obţinut şi în ceea ce priveşte forţa musculară de la nivelul degetelor astfel, la flexorii degetelor 2-5 forţa musculară a crescut la 5 de la valori de 3,5 şi la haluce de la 2 la forţă 5 .

La extensorii halucelui (F0 iniţial) forţa musculaă a crescut la 5, iar la extensorii degetelor 2-5, forţa a crescut de la 2 la 5; abductorii degetelor având în final o forţă de 5 comparativ cu 0 iniţial.

Creşterea forţei musculare reprezintă de fapt o refacere a traiectului nervos şi o inervaţie normală a muşchilor afectaţi.
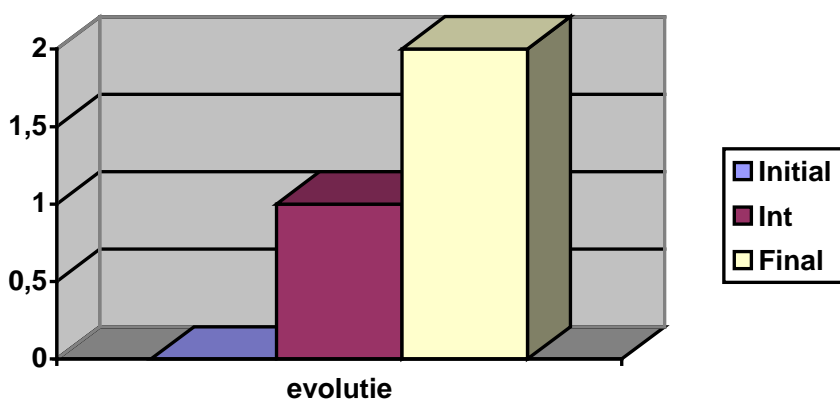

Figura 8. Evoluţia sensibilităţii cutanate 
Aşa cum reiese din graficul nr. 8 şi tabelul nr. 4, sensibilitatea a revenit la valori normale (2) de la hipoestezie (0) la nivelul părţii antero- externe a gambei şi piciorului.

Recuperarea paraliziei de nerv sciatic popliteu extern prin neurapraxie post-chirurgical, după îndepărtarea compresiunii nervului are o durată variabilă, între 6 şi 9 luni şi presupune abordarea unei strategii specifice, bazată pe folosirea musculaturii normal inervate pentru a influenţa musculatura paralizată, fenomen cunoscut în literatura de specialitate sub denumirea de facilitare. Durata recuperării este dependentă de: precocitatea începerii recuperării, , motivaţia pacientului, nivelul de pregătire a specialistului prin folosirea adecvată a tehnicilor, procedeelor şi metodelor specifice în diferite etape ale tratamentului.

\section{Concluzii}

În studiul realizat cu privire la rolul tehnicilor de facilitare în recuperarea paraliziei de nerv sciatic popliteu exten prin neurapraxie post-chirurgical, ipoteza de la care am plecat s-a confirmat. În acest sens, se pot formula unele concluzii, astfel:

- Folosirea în perioada de hipotonie musculară (F0-1) a stretchreflexului, contracţiilor repetate, mişcării active de relaxare opunere pe musculatura paralizată şi secvenţialităţii pentru întărire pe musculatura normală (pentru a influenţa muşchii afectaţi), grăbeşte apariţia răspunsul motor;

- Aplicarea inversării lente şi a inversării lente cu opunere (F 2-4) are eficienţă în restabilirea echilibrului dintre agonişti şi antagonişti, prin adaptarea rezistenţei opuse la forţa de moment a muşchiului;

- Izometria alternantă şi stabilizarea ritmică, cresc forţa musculară şi stabilitatea articulară prin contracţia concomitentă a agoniştilor, antagoniştilor, sinergiştilor şi fixatorilor;

- Selectarea celor mai eficiente tehnici de facilitare în funcţie de forţa muşchiului este esenţială pentru grăbirea apariţiei răspunsului motor.

În final, rolul tehnicilor de facilitare în refacerea funcţională a nervului este de necontestat, esenţială fiind selectarea lor în funcţie de: tipul de leziune al nervului, forţa muşchiului, abilitatea practică şi modalitatea de comunicare a kinetoterapeutului; toate acestea culminând cu scurtarea timpului de recuperare la jumătate comparativ cu folosirea mijloacelor clasice de recuperare. 